\title{
Eutrophication and vertical flux: a critical evaluation of silicate addition
}

\author{
Camilla Svensen* \\ Norwegian College of Fishery Science, University of Tromsø, 9037 Tromsø, Norway
}

\begin{abstract}
Availability of dissolved silicate (DSi) can affect phytoplankton species composition and the pelagic-benthic coupling. Further, consumption of DSi is assumed to be proportional to export production and sedimentation. The effect of DSi on the vertical flux of biogenic matter was investigated in 4 mesocosm experiments, where all enclosures were fertilised with nitrate and phosphate (NP), while half of the enclosures were given DSi as well (NPS). Sedimentation rates were expected to increase with consumption of DSi according to the 'silicate-sedimentation' hypothesis, as a result of diatom aggregate formation and/or increased faecal pellet production form diatom-grazing copepods. Diatoms and faecal pellet carbon did contribute significantly more to the vertical flux in the NPS than in the NP enclosures. However, sedimentation of particulate organic carbon (POC) was still not significantly different between the NP and NPS treatments. This was due to high sedimentation rates of Phaeocystis pouchetii in the NP enclosures. The results of these experiments indicate that the relationship between DSi and daily carbon export is not necessarily as simple as suggested by the silicate-sedimentation hypothesis. Much of the uncertainties concerning the hypothesis are related to the sedimentation of $P$. pouchetii, as they contribute not only cell carbon but also mucilagenous matter.
\end{abstract}

KEY WORDS: Vertical flux $\cdot$ Eutrophication $\cdot$ Silicate $\cdot$ Mesocosm

\section{INTRODUCTION}

The hypothesis that declining silica concentrations influence the sequence of seasonal succession of diatoms in freshwater systems (Kilham 1971, Schelske \& Stoermer 1971) has stimulated research on the effect of macronutrient composition on the phytoplankton community also in marine environments (cf. Officer \& Ryther 1980, Sommer 1996, Egge 1997). It has been suggested that the sequence from diatom-dominated spring blooms to a late summer to early fall flagellate dominance is controlled by the silicate regeneration cycle (Smayda 1990). Consequently, increased sewage inputs and declining dissolved silicate (DSi) supplies (Conley et al. 2000) to a confined estuarine or coastal water body may replace diatoms with species not requiring DSi for growth (Turner et al. 1998). Altered

*E-mail: camillas@nfh.uit.no nutrient ratios caused by anthropogenic eutrophication are also associated with intensified blooms of novel and nuisance phytoplankton blooms (e.g. Officer \& Ryther 1980, Smayda 1990, Conley et al. 1993). From the perspective of eutrophication, it is important to know in detail how phytoplankton biomass and species composition respond to the composition of nutrients. However, it is also essential to understand the mechanisms determining the fate of the phytoplankton bloom (sedimentation versus regeneration in the photic zone) under various nutrient regimens.

On time scales of months and years, sedimentation of biogenic matter is assumed to be positively correlated with new production (sensu Eppley \& Peterson 1979) and hence with the supply of nitrate. In areas where diatoms carry out a major fraction of the new production (like coastal and upwelling areas), silicate, and not nitrate, has been suggested to be the regulating nutrient for new production (Ku et al. 1995, Dugdale \& Wilkerson 1998). Based on these assumptions, it is con- 
cluded that DSi availability increases the draw-down of $\mathrm{CO}_{2}$ from the atmosphere (e.g. Pollock 1997). DSi has also been suggested as a 'remedy' for eutrophicated areas by triggering growth of diatoms, increasing carbon export and thereby removing excess nutrients from the water column (Wassmann et al. 1996). Knowing the role of DSi for vertical flux is therefore of crucial importance for our understanding of humaninduced eutrophication as well as for the global oceanic carbon cycle in the ocean.

This study investigated the effect of DSi on the vertical flux of biogenic matter in enclosed ecosystems. Of importance is how well the above-mentioned assumptions of DSi-regulated sedimentation are met on the short time scales of weeks. Does silicate fertilisation increase sedimentation and, if not, why? Data are derived from 4 separate mesocosm experiments. While each experiment was designed to test various hypotheses, the experimental design allows the comparison of sedimentation in silicate-replete versus silicate-depleted enclosures.

\section{MATERIALS AND METHODS}

The 4 mesocosm experiments were conducted during 1996 to 1998 (Table 1) at a location in the Raunefjord, western Norway (for a description of the location see www.ifm.uib.no/LSF/inst2.html). Each experiment consisted of eight $27 \mathrm{~m}^{3}$ (depth $9.3 \mathrm{~m}$, diameter $2 \mathrm{~m}$ ) polyethylene enclosures with $90 \%$ light penetration (photosynthetically active radiation [PAR]). The experiments were conducted in September 1996, April 1997, April and May 1998, and August 1998, and will be referred to as Expts 1 to 4, respectively. Two enclosures were excluded from Expt 1 because they had holes. The duration of the experiments was 18 to $24 \mathrm{~d}$. More information on the enclosures and the filling procedure can be found in Svensen et al. (2001). Briefly, the enclosures were filled with unfiltered seawater from $5 \mathrm{~m}$ depth, except Expt 3, where the seawater was pre-screened for zooplankton $>90 \mu \mathrm{m}$. A pycnocline was created in all enclosures at approximately $4 \mathrm{~m}$ depth by filling the bottom layer with denser water (Expt 2) or by adding fresh water to the upper layer (Expts 1, 3 and 4). An air-lift system (Svensen et al. 2001) penetrating to $4 \mathrm{~m}$ depth provided circulation in the upper part of the enclosures.

Each of the experiments was designed to test specific hypotheses concerning vertical flux of biogenic matter (Table 1). Expts 1 and 2 tested the combined effect of turbulence and DSi (treatments given to duplicate enclosures), Expt 3 the effect of different concentrations of large calanoid grazers and Expt 4 the effect of nutrient pulsing. Nitrate was added as $\mathrm{NaNO}_{3}$, phosphate as $\mathrm{KH}_{2} \mathrm{PO}_{4}$ and silicate as $\mathrm{Na}_{2} \mathrm{SiO}_{3} \cdot 5 \mathrm{H}_{2} \mathrm{O}$. Initial nutrient loads are presented in Table 1. Enclosures fertilised with only nitrate and phosphate are termed NP, and silicate-fertilised enclosures NPS. The total DSi consumption in each enclosure was calculated based on DSi added and the concentration at 2 and $6 \mathrm{~m}$ depths at the beginning and end of the experiment. Only results concerning vertical flux of particulate organic carbon (POC), faecal pellet carbon (FPC) and phytoplankton carbon (PPC) from the dominating groups are considered here.

Sedimentation was measured in each enclosure with cylindrical sediment traps (aspect ratio 6.25) immersed in the centres of the enclosures at $8 \mathrm{~m}$ depth. The sediment traps consisted of cylinders of transparent plexiglass mounted in a gimballed frame. Traps were deployed for $48 \mathrm{~h}$ in Expts 1 and 2 and for $24 \mathrm{~h}$ in Expts 3 and 4 . No preservative was used during deployment. Triplicate subsamples from the sediment traps were analysed for POC by filtering onto pre-combusted Whatman GF/F filters and analysed on a Leeman Lab CEC 440 elemental analyser after removal of carbonate with fuming of $\mathrm{HCl}$. Zooplankton were as far as possible (visually) removed from the filters (Lee et al. 1988). Subsamples of $100 \mathrm{ml}$ were taken from the sediment traps for enumeration and identification of phytoplankton and faecal pellets. These samples were

Table 1. Overview of the 4 experiments. All enclosures were fertilised with nitrate and phosphate (NP enclosures) and half with NP plus dissolved silicate (DSi) (NPS enclosures). Final concentrations of the initial loads of nitrate (N), phosphate (P) and silicate (Si) in the upper part $\left(12.5 \mathrm{~m}^{3}\right)$ of the enclosures are shown. Note that treatments in Expts 1 and 2 were given to duplicate enclosures (2 NP and 2 NPS), and the averages of the 2 are presented throughout this paper. In Expts 3 and 4 one NP and one NPS enclosure received the same treatment

\begin{tabular}{|llll|}
\hline Expt & Time of study & Treatments & Initial loads of N, P and Si $(\mu M)$ \\
\hline 1 & September 1996 & Two levels of turbulence (duplicate treatments) & $1.5: 0.1: 1.5$ \\
2 & April 1997 & Two levels of turbulence (duplicate treatments) & $15: 1: 10$ \\
3 & April/May 1998 & Four concentrations of Calanus finmarchicus & $5: 0.3: 5$ \\
& & $\left(0,40,150\right.$ and 600 copepods m ${ }^{-3}$ ) & $15: 1: 10$ \\
\hline
\end{tabular}


preserved with a Lugol's solution of $2 \%$ final concentration (Rousseau et al. 1990). Phytoplankton was counted and identified using a non-inverted light microscope furnished with a counting stage (Semina 1978). Three different size classes were counted in 3 steps using the appropriate sample volume and magnification, as described by Ratkova et al. (1999). The smallest cell size that can be enumerated with this method is 2 to $4 \mu \mathrm{m}$. Biovolumes of individual cells were calculated from linear dimensions of measured cells applied to appropriate stereometric formulae (Smayda 1978). The PPC content was then calculated based on the average volume of different species and according to Strathmann (1967). Faecal pellets were counted and measured (length and width) in a $1 \mathrm{ml}$ chamber at $100 \times$ magnification, and were then converted to carbon using a volumetric carbon conversion factor of $69.4 \mu \mathrm{g} \mathrm{C} \mathrm{mm} \mathrm{m}^{-3}$ according to Riebesell et al. (1995). The total number of enclosures available for analysis is 30 . In the cases where treatments were given to duplicate enclosures, the average is presented. Furthermore, not all parameters were analysed in each enclosure (for POC, FPC and PPC, n $=24$ enclosures, but for DSi consumption, $\mathrm{n}=30$ enclosures). Differences between treatments were statistically tested by using a 1 -tailed $t$-test on average sedimentation rates for each enclosure. The level of significance is $\mathrm{p} \leq 0.05$.

\section{RESULTS AND DISCUSSION}

As a test of the hypothesis that DSi consumption and sedimentation of carbon are positively correlated (e.g. the 'silicate-sedimentation' hypothesis sensu Wassmann et al. 1996), vertical flux was compared between the NP and NPS enclosures. Support of the hypothesis implies significantly higher sedimentation rates of POC in the NPS than in the NP enclosures, but no such trend was found. On the contrary, when all available daily sedimentation rates of POC $(n=106)$ were compared, sedimentation rates were higher in the NP than in the NPS enclosures ( $p<0.05)$ (Fig. 1A). However, using average rates for each enclosure $(n=24)$ and identifying data belonging to the various experiments show that this result is mainly due to high sedimentation rates (in the NP enclosures) in Expt 2 (Fig. 1B). Otherwise, sedimentation rates were quite similar in the NP and NPS environments, and no statistical difference was found between the 2 nutrient regimens $(p>0.05)$. This means that the silicate-sedimentation hypothesis could not be supported for POC export in these experiments.

New and export production are assumed to be in balance with biogenic silica (Dugdale \& Wilkerson
1998). This conclusion was also drawn from an earlier mesocosm experiment (same locality and technology as in the present experiments), where the addition of DSi increased the vertical export by $18 \%$ (Wassmann et al. 1996). That experiment was the first (to the best of my knowledge) to relate short-time sedimentation of carbon with DSi consumption. However, one shortcoming with their experiment was the lack of replicates, meaning that all differences between the 2 enclosures (NP and NPS) were interpreted as a result of DSi consumption.

In the present 4 mesocosm experiments (with 30 enclosures available for analysis), the relationship between consumed DSi and carbon sedimentation is less clear (Fig. 2). For example, the largest range (400 to $1700 \mathrm{mg} \mathrm{C} \mathrm{m}^{-2} \mathrm{~d}^{-1}$ ) in vertical flux was associated
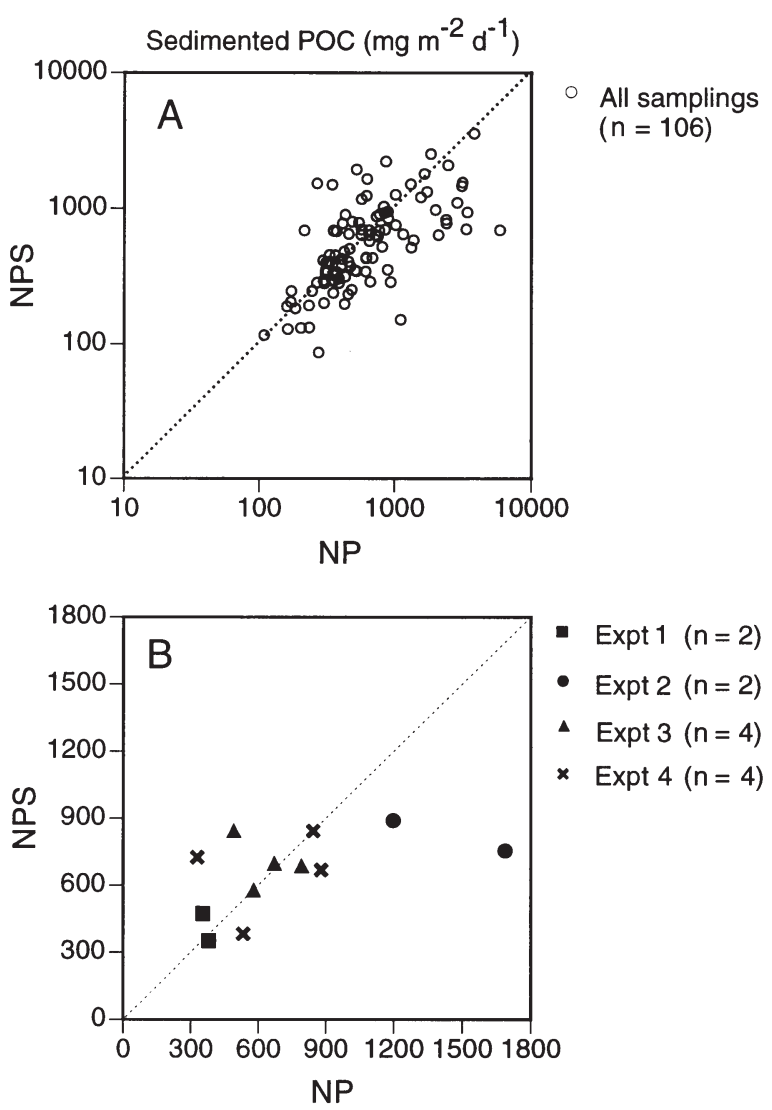

Fig. 1. (A) Daily sedimentation rates (mg particulate organic carbon [POC] $\mathrm{m}^{-2} \mathrm{~d}^{-1}$ ) in nitrogen and phosphate (NP) versus NP plus silicate (NPS) enclosures in Expts 1 to 4 . All measurements are presented to include the full range of variability. Each data point represents 1 sampling date, except in Expts 1 and 2, where duplicate enclosures were averaged. (B) Same as (A), except that flux is depicted as total sedimentation rate enclosure $^{-1}$ period $^{-1}$, corrected for experimental duration. In Expts 1 and 2, $\mathrm{n}=2$ because the average rate is presented for 2 replicate treatments. The dotted lines indicate the 1:1 relationship between vertical carbon export in NPS and NP enclosures. Note different scales 


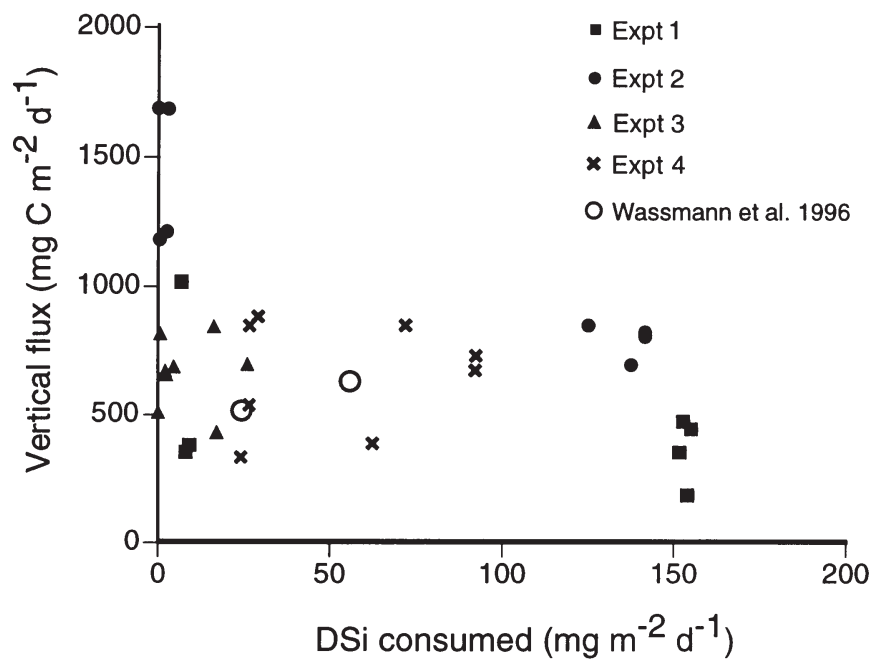

Fig. 2. Relationship between POC export $\left(\mathrm{mg} \mathrm{m}^{-2} \mathrm{~d}^{-1}\right)$ and dissolved silicate (DSi) consumption $\left(\mathrm{mg} \mathrm{m}^{-2} \mathrm{~d}^{-1}\right)$ in Expts 1 to 4 . Vertical flux is depicted as total sedimentation rate enclosure ${ }^{-1}$ period $^{-1}$ corrected for experiment duration

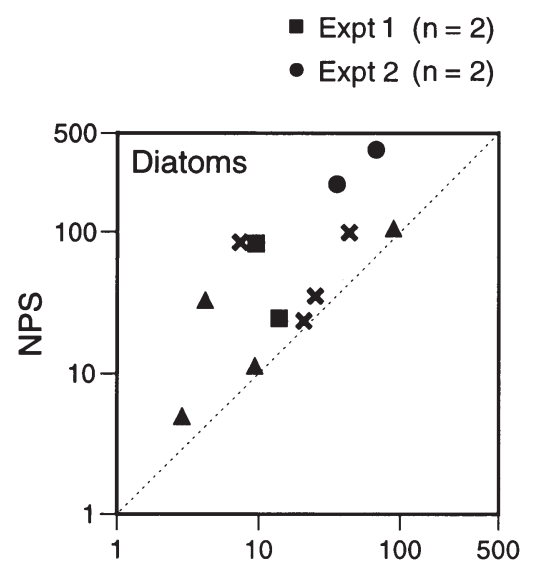

Axpt $3(n=4)$

$\times$ Expt $4(n=4)$

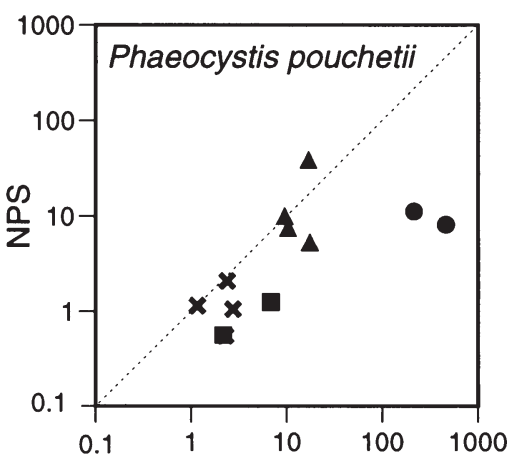

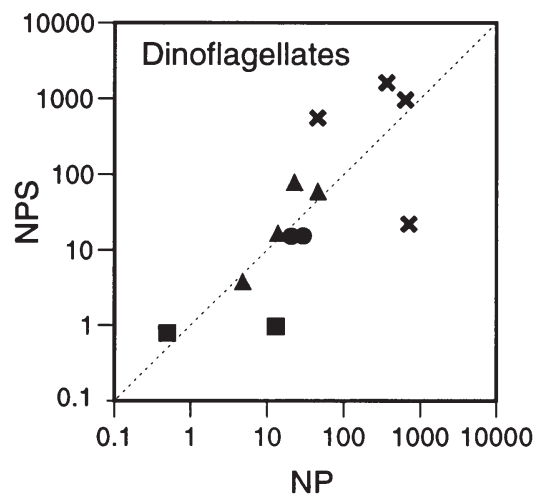

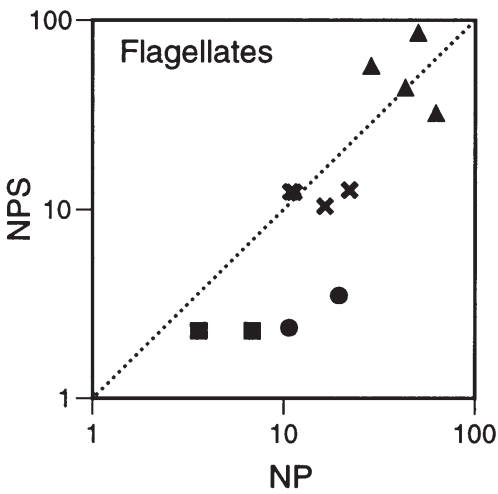

Fig. 3. Daily sedimentation rates (mg phytoplankton carbon [PPC] $\mathrm{m}^{-2} \mathrm{~d}^{-1}$ ) for diatoms, Phaeocystis pouchetii (including single cells and cells in colonies), dinoflagellates and flagellates. Vertical flux rates are calculated as in Fig. 1B. The dotted lines indicate the 1:1 relationship between export in NPS and in NP enclosures. Note different scales with low consumption of DSi (i.e. in the NP enclosures), illustrating the problem of predicting vertical flux for non-diatom communities. The highest flux rates of POC were measured in the NP enclosures in Expt 2 (Fig. 1B), and this was associated with high sedimentation rates of Phaeocystis pouchetii (Fig. 3). There is a general trend of higher sedimentation rates of $P$. pouchetii when all experiments are compared (Fig. 3), although it is not statistically significant $(p=0.09)$. On the other hand, the diatoms contributed gnificantly more to the vertical flux in NPS than in NP closures $(\mathrm{p}<0.05)$. The range of sedimented diatom on in the NPS enclosures was about 10 to $500 \mathrm{mg} \mathrm{C}$ $\mathrm{d}^{-1}$, while the range of $P$. pouchetii in the NP (Fig. 3). therefore appears that the expected effect of DSi addition (i.e. increased flux of diatoms) to the systems pouchetii. A sedimenting material has also been reported at $50 \mathrm{~m}$ depth in the Barents Sea (Wassmann et al. 1990). The vertical flux of dinoflagellates and flagellates did not appear to be dependent on nutrient treatments $(\mathrm{p}=0.18$ and $\mathrm{p}=0.4$, respectively).

In close accordance with the hypothesis, sedimentation of FPC (Fig. 4) was significantly higher in the NPS than in the NP replicates $(\mathrm{p}<0.05)$. A positive relationship between DSi and faecal pellet sedimentation has also been reported in situ (Turner et al. 1998), and was explained by selection of copepods when diatoms are prevailing (at DSi:N ratios >1). This does not explain the increased flux of FPC in the present experiments, as the composition of mesozooplankton was quite similar in the NP and NPS enclosures (J. C. Nejstgaard pers. comm.). However, copepods grazing diatoms produce larger FP than copepods grazing 'naked' cells (such as flagellates). This has been demonstrated both in the laboratory (Båmstedt et al. 1999) and in mesocosms (Nejstgaard et al. 2001b). Lower assimilation efficiency on refractory material (such as diatom/coccolithophore frustules) also causes higher egestion rates (Båmstedt et al. 1999). Since the higher FPC sedimentation rates in the NPS enclosures were not directly coupled to higher grazing 


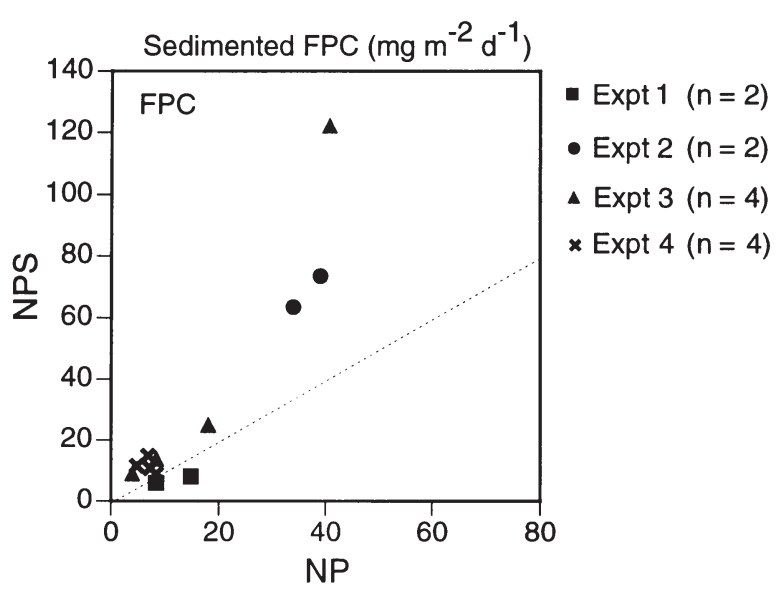

Fig. 4. Daily sedimentation rates of faecal pellet carbon (FPC) (mg FPC m$~^{-2} \mathrm{~d}^{-1}$ ) in Expts 1 to 4 . Vertical flux rates are calculated as in Fig. 1B

rates (Nejstgaard et al. 1997, 2001a), it is unclear whether the result may be regarded as supporting the silicate-sedimentation hypothesis.

The data presented here indicate that increased diatom production does not necessarily cause increased carbon sedimentation, even though the relative flux of diatoms was higher in the NPS than in the NP enclosures. Hence, the lack of support for the silicate-sedimentation hypothesis was most likely caused by the high sedimentation rates of Phaeocystis pouchetii in the NP enclosures 'masking' the increased diatom flux. However, the lack of support for the silicate-sedimentation hypothesis regarding POC may also be caused by experimental shortcomings. First of all, pelagic production and export may be coupled on long time scales (like months and years) but decoupled on the short time scales of weeks. This was for instance demonstrated in the Norwegian Sea, where the sedimented material peaked several months after maximum production (Wassmann et al. 1991). Extending the duration of experiments could in theory solve this problem, although with the technology used herein such a prolongation would probably introduce more severe bag effects. However, extending the duration of the experiments may not necessarily lead to support for the hypothesis. For instance, the Marine Ecosystems Research Laboratory (MERL) tanks were run for $1 \mathrm{yr}$ and demonstrated that lowering the $\mathrm{N}: \mathrm{Si}$ ratio from 16 to 1 increased the abundance of diatoms, while it had little effect on the visual quality of the water or the oxygen concentration in the benthos (Doering et al. 1989), implying that sedimentation rates of carbon were not significantly changed.

It should also be noted that measuring sedimented matter in a flexible-wall mesocosm almost certainly overestimates the loss rates of biogenic matter (Wass- mann et al. 1996, Svensen et al. 2001). It has been suggested that the circulation system used in the present experiments may have directed the material in the lower layer of the enclosures from the outer walls towards the centre and the sediment traps (Svensen 2001). One may assume that this artefact caused similar relative overestimates in all mesocosms and that general trends such as vertical flux in NP compared to NPS should still be valid. However, focusing of small detrital particles, mucilaginous matter and flagellates could be more influenced by the circulation pattern than that of larger, denser particles. Thus, the high vertical POC export, in particular in the NP enclosures with their dominance of flagellates and Phaeocystis pouchetii, may be an artefact.

To summarise, the silicate-sedimentation hypothesis was tested using a compilation of data derived from 4 mesocosm experiments. POC sedimentation rates were not statistically different between the NP and NPS enclosures and the hypothesis was therefore not supported. However, a more detailed investigation of the sedimented material revealed that the hypothesis was supported for diatoms, as significantly higher sedimentation rates were found in NPS than in NP enclosures. In contrast, the vertical flux of Phaeocystis pouchetii was higher in the NP than in the NPS enclosures, and this may have masked the effect of DSi addition. Data obtained from mesocosms may not be directly comparable to natural situations, but the present experiments indicate that the relationship between DSi and daily carbon export is not necessarily as simple as suggested by a previous mesocosm experiment (Wassmann et al. 1996). Many of the uncertainties concerning the hypothesis are related to the sedimentation of $P$. pouchetii, as they contribute not only cell carbon, but also mucilagenous matter such as transparent exopolymer particles (TEP). The latter can induce increased vertical export of both cell carbon and detritus.

Acknowledgements. O. Sergeeva is acknowledged for counting and enumeration of phytoplankton and faecal pellets, $\mathrm{S}$. Øygarden for POC analyses and J. K. Egge for providing data on DSi consumption. The manuscript was improved through the constructive comments of T. Tamminen, P. Wassmann, D. J. Conley and C. Wexels Riser. Financial support was provided by a Norwegian Research Council (NFR) grant to J. K. Egge and P. Wassmann and partly by a NorFA grant to C. Svensen. This is a contribution from the Norwegian Programme Nutrients and Pelagic Marine Production (NAPP).

\section{LITERATURE CITED}

Båmstedt U, Nejstgaard JC, Solberg PT (1999) Utilisation of small-sized food algae by Calanus finmarchicus (Copepoda, Calanoida) and the significance of feeding history. Sarsia 84:19-38 
Conley DJ, Schelske CL, Stoermer EF (1993) Modification of the biogeochemical cycle of silica with eutrophication. Mar Ecol Prog Ser 101:179-192

Conley DJ, Stålnacke P, Pitkänen H, Wilander A (2000) The transport and retention of dissolved silicate by rivers in Sweden and Finland. Limnol Oceanogr 45:1850-1853

Doering PH, Oviatt CA, Beatty LL, Banzon VF, Rice R, Kelly SP, Sullivan BK, Frithsen JB (1989) Structure and function in a model and coastal ecosystem: silicon, the benthos and eutrophication. Mar Ecol Prog Ser 52:287-299

Dugdale RC, Wilkerson FP (1998) Silicate regulation of new production in the equatorial Pacific upwelling. Nature 391:270-273

Egge JK (1997) Are diatoms poor competitors at low phosphate concentrations? J Mar Syst 16:191-198

Eppley RW, Peterson BJ (1979) Particulate organic matter flux and planktonic new production in the deep ocean. Nature 282:677-680

Kilham P (1971) A hypothesis concerning silica and the freshwater planktonic diatoms. Limnol Oceanogr 16:10-18

Ku TL, Luo S, Kusakabe M, Bishop JKB (1995) ${ }^{228}$ Ra-derived nutrient budgets in the upper equatorial Pacific and the role of 'new' silicate in limiting productivity. Deep-Sea Res 42:479-497

Lee C, Wakeham SG, Hedges JI (1988) The measurement of oceanic particle flux: are 'swimmers' a problem? Limnol Oceanogr 1:34-36

Nejstgaard JC, Gismervik I, Solberg PT (1997) Feeding and reproduction by Calanus finmarchicus and microzooplankton grazing during mesocosm blooms of diatoms and the coccolithophore Emiliania huxleyi. Mar Ecol Prog Ser 147:197-217

Nejstgaard JC, Hygum BH, Naustvoll LJ, Båmstedt U (2001a) Zooplankton growth, diet and reproductive success compared in simultaneous diatom- and flagellate-microzooplankton-dominated plankton blooms. Mar Ecol Prog Ser 221:77-91

Nejstgaard JC, Naustvoll LJ, Sazhin A (2001b) Correcting for underestimation of microzooplankton grazing in bottle incubation experiments with mesozooplankton. Mar Ecol Prog Ser 221:59-75

Officer CB, Ryther JH (1980) The possible importance of silicon in marine eutrophication. Mar Ecol Prog Ser 3:83-91

Pollock DE (1997) The role of diatoms, dissolved silicate and Antarctic glaciation in glacial/interglacial climatic change: a hypothesis. Global Planet Change 14:113-125

Ratkova TN, Wassmann P, Verity PG, Andreassen IJ (1999)

Editorial responsibility: Otto Kinne (Editor),

Oldendorf/Luhe, Germany
Abundance and biomass of pico-, nano- and microplankton along a transect on Nordvestbanken, north Norwegian shelf, in 1994. Sarsia 84:213-225

Riebesell U, Reigstad M, Wassmann P, Noji T, Passow U (1995) On the trophic fate of Phaeocystis pouchetii (Hariot): VI Significance of Phaeocystis-derived mucus for vertical flux. Neth J Sea Res 33:193-203

Rousseau V, Mathot S, Lancelot C (1990) Calculating carbon biomass of Phaeocystis sp. from microscopic observations. Mar Biol 107:305-314

Schelske CL, Stoermer EF (1971) Eutrophication, silica depletion, and predicted changes in algal quality in Lake Michigan. Science 173:423-424

Semina H (1978) Treatment of an aliquot sample. In: Sournia A (ed) Phytoplankton manual. UNESCO, Paris, p 181

Smayda TJ (1978) From phytoplankters to biovolume. In: Sournia A (ed) Phytoplankton manual. Unesco Publications, Paris, p 273-279

Smayda TJ (1990) Novel and nuisance phytoplankton blooms in the sea: evidence for a global epidemic. In: Granéli E, Sundström B, Edler L, Anderson D (eds) Toxic marine phytoplankton. Elsevier, New York, p 29-40

Sommer U (1996) Marine food webs under eutrophic conditions: desirable and undesirable forms of nutrient richness. Dtsch Hydrogr Z Suppl 6:167-176

Strathmann RR (1967) Estimating the organic carbon content of phytoplankton from cell volume or plasma volume. Limnol Oceanogr 12:411-418

Svensen C (2001) Vertical flux regulation in experimental ecosystems: impact of nutrients and grazers. DrS thesis, University of Tromsø

Svensen C, Egge JK, Stiansen JE (2001) Can silicate and turbulence regulate the vertical flux of biogenic matter? A mesocosm study. Mar Ecol Prog Ser 217:67-80

Turner RE, Qureshi N, Rabalais NN, Dortch Q, Justic D, Shaw RF, Cope J (1998) Fluctuating silicate:nitrate ratios and coastal plankton food webs. Proc Natl Acad Sci USA 95:13048-13051

Wassmann P, Vernet M, Mitchell BG, Rey F (1990) Mass sedimentation of Phaeocystis pouchetii in the Barents Sea. Mar Ecol Prog Ser 66:183-195

Wassmann P, Peinert R, Smetacek V (1991) Patterns of production and sedimentation in the boreal and polar Northeast Atlantic. Polar Res 10:209-228

Wassmann P, Egge JK, Reigstad M, Aksnes DL (1996) Influence of dissolved silicate on vertical flux of particulate biogenic matter. Mar Pollut Bull 33:1-6

Submitted: December 18, 2001; Accepted: May 7, 2002

Proofs received from author(s): August 2, 2002 